\section{3 and 2014 National Science Foundation Political Science Program Awards}

The political science program announces its awards for basic research support and dissertation improvement grants for fiscal years 2013 and 2014. In 2013, the program funded eight regular awards, 14 doctoral dissertation improvement awards, and one Grant for Rapid Response Research (RAPID) award in addition to several continuing grant increments. RAPID awards support research where scholars must get into the field immediately to collect data concerning unplanned events. Grant increments are disbursements of funds for awards that were made in a previous fiscal year but for which funds are disbursed on a yearly basis instead of upfront.

The number of awards for the 2013 fiscal year was fewer than normal because of the restrictions placed on the program through the passage of the 2013 Federal Continuing Appropriation Act, delaying some awards to 2014. The program held both fall and spring competitions, but was required to undertake additional consideration of the proposals submitted for the spring competition. Awards from the spring 2014 competition were awarded in fiscal year 2014 .

In 2014, the program funded 33 regular awards, 30 doctoral dissertation improvement awards, and seven Early Concept Grants for Exploratory Research (EAGER) and RAPID awards in addition to several continuing grant increments. EAGER awards support research that is exploratory or on the cutting edge. Grants increments are disbursements of funds for awards that were made in a previous fiscal year but for which funds are disbursed on a yearly basis instead of upfront. The program disbursed approximately \$9.7 million during the 2014 fiscal year.

Like 2013, fiscal year 2014 was an unusual one for the political science program at NSF. Because of the uncertainty that arose from 2013 Federal Continuing Appropriation Act, the Political Science program canceled the fall 2013 competitions. Thus, these awards represent a mix of proposals that were submitted in January of 2013 and January 2014.

\section{REGULAR AWARDS}

With regular awards, the first principal investigator for each project is listed.

Blattman, Christopher, Columbia University, "Experimentally Testing the Roots of Poverty and Violence: Changing Preferences, Behaviors, and Outcomes"

Dolan, Julie, Macalester College, "RUI:

Representative Bureaucracy and Improving Health Care for Female Veterans"

Gibler, Douglas, University of Alabama, "Intradispute Bargaining: Collecting and Coding Individual Incidents in the Militarized Interstate Dispute (MID) Data, 1816-2001"

Hatemi, Peter, Pennsylvania State University, "Workshop: Methodological Training Opportunity for Politics and Genetics"

Huckfeldt, Robert, University of California, Davis, Workshop: "Support for Political Networks Conference and Training Workshops" (Co-funded with the Measurement, Methodology and Statistics Program)

Schrodt, Philip, Pennsylvania State University, Collaborative Research: "Automated Real-time Production of Political Indicators" (Co-funded with the MeaProgram)

Stewart, Charles, Massachusetts Institute of Technology, Workshop: "Workshop on the Science of Voting Technology:

Ward, Michael, Duke University, Collaborative Research: "Automated Realtime Production of Political Indicators" (Co-funded with the Methodology, Measurement, and Statistics Program)

\section{DISSERTATIONS}

With Doctoral Dissertation Research Improvement Grants, the advisor is listed first with the student listed second.

Binder, Sarah and Jake Haselwert, George Washington University, "Policy Tools and Public Opinion"

Carsey, Thomas and Chelsea J. Phillips, University of North Carolina, Chapel Hill "The Role of Political Attitudes in Social Interaction Dyads"

Diaz-Cayeros, Alberto and Rogelio A. Ruiz Euler, University of California, San Diego "Electoral Competition, Income Inequality, and Public Goods: A Subnational Assessment" surement, Methodology and Statistics Research and Education"
Dominguez, Jorge and Alisha Holland, "Enforcement Politics and Social Policy in Urban Latin America"

Hajnal, Zoltan and Lindsay Nielson, University of California, San Diego, "Demographics and Voter Participation"

Imai, Kosuke and In Song Kim, Princeton University, "Open Trade for Sale: Lobbying by Productive Exporting Firms"

Kier, Elizabeth and Stephan Hamburg, University of Washington, "Electoral Violence in New Democracies: The Institutional Foundations of Peaceful Transitions"

Perez-Linan, Anibal and John Polga-Hecimovich, University of Pittsburgh, "The Delegation of Bureaucratic Policymaking Authority in Latin America"

Mettler, Suzanne and Danielle M. Thomsen, Cornell University, "Partisan Polarization and the Representation of Women in the U.S. Congress"

Nelson, Thomas E. and Dustin Carnahan, Ohio State University, "Why Motivations Matter: Information Processing Goals and Their Implications for Selective Exposure to Political Information"

Rosenbluth, Frances and Dawn L. Teele, Yale University, "Descriptive Representation and Policy Outcomes in Parliaments"

Seligson, Mitchell and Mason W. Moseley, Vanderbilt University, "Ballots and Blockades: The Normalization of Protest in Latin America"

Snyder, Jack and Jonathan S. Blake, Columbia University," Participation in Loyalist Protest Activities in Northern Ireland"

Stevenson, Randolph T. and Seonhgui Lee, Rice University, "What Makes Politics Interesting?"

\section{RAPID}

Golden, Miriam, University of California, Los Angeles, "The Impact of Domestic Election Observers on Electoral Violence, Integrity, and Voting Behavior"

\section{REGULAR AWARDS}

With regular awards, the first principal investigator for each project is listed.

Amaney, Jamal, Princeton University, Collaborative Research: "Experimental Research on Religious Scripture and Political Behavior in the Muslim World" 
Ansolabehere, Stephen, Harvard University, "2014 Cooperative Election Study"

Berman, Eli, University of California, San Diego, Workshop: "Effective Development in Fragile States"

Bhamidi, Sreekalyani, University of North Carolina, Chapel Hill, Collaborative Research: "Specification and Estimation of Exponential Family Random Graph Models for Weighted Networks" (Co-funded with the Methodology, Measurement and Statistics Program)

Burns, Nancy, University of Michigan, Ann Arbor, "The Fifth Module of the Comparative Study of Electoral Systems (CSES)"

Coppedge, Michael, University of Notre Dame, Collaborative Research: "Institutions, Development, and Democracy"

Desmarais, Bruce A., University of Massachusetts, Amherst, Collaborative Research: "Specification and Estimation of Exponential Family Random Graph Models for Weighted Networks" (Co-funded with the Methodology, Measurement, and Statistics Program)

Elman, Colin, Syracuse University, Workshop: "Support for Institutes and Research Groups on Qualitative and Multi-Method Research: 2015-2017"

Elman, Colin, Syracuse University, "Qualitative Data Depository"

Elman, Colin, Syracuse University, "Qualitative Data Depository 2015-2016"

Esarey, Justin, Rice University, "An Online International Methods Colloquium for Quantitative Methodology in Political Science"

Frye, Timothy, Columbia University, Collaborative Research: "Voter Mobilization and Electoral Subversion in the Workplace"

Gerring, John, Trustees of Boston University, Collaborative Research: "Institutions, Development, and Democracy"

Gibson, Clark, University of California, San Diego, "Transparency, Accountability and Corruption Displacement"

Gornick, Janet, CUNY Graduate School University Center, "The Development of Cross-National Income and Wealth Databases: The Luxembourg Income and Wealth Studies 2014-2018" (Cofunded with the Economics, Methodology, Measurement and Statistics, and Sociology Programs)

Granato, Jim, University of Houston, Workshop: "Support for Graduate Students at the University of Houston EITM Summer Training Institute"
Hillygus, Sunshine, Duke University, "Education, Engagement, and WellBeing among Adolescents"

Humphreys, Macartan, Columbia University, "Political Communication and Accountability in Uganda"

Hutchings, Vincent, University Michigan, Ann Arbor, Collaborative Research: "American National Election Studies (ANES) 2014-2017"

Kelley, Judith, Duke University, "US Efforts to Influence Government Policies on Human Trafficking" (Co-funded with the Law and Social Science Program)

Martin, Isaac, University of CaliforniaSan Diego, "Direct Democracy and the Significance of the Framing of Proposals" (Co-funded with the Law and Social Science Program)

Masoud, Tarek, Harvard University, Collaborative Research: "Experimental Research on Religious Scripture and Political Behavior in the Muslim World"

Mershon, Carol, University of Virginia, Main Campus, Workshop: "Collaboration across Diverse Groups to Improve Scholarship" (Co-funded with the Law and Social Science Program)

Palfrey, Thomas, California Institute of Technology, "Theoretical and Experimental Research on Voting and Bargaining Games" (Co-funded with the Economics program)

Pemstein, Daniel, North Dakota State University, Fargo, Collaborative Research: "Institutions, Development, and Democracy"

Quinn, Kevin, University of CaliforniaBerkeley, Workshop: "Support for Conferences and Mentoring of Underrepresented Groups in Political Methodology" (co-funded with the Measurement, Methodology and Statistics Program)

Reuter, Ora J., University of WisconsinMadison, Collaborative Research: "Voter Mobilization and Electoral Subversion in the Workplace"

Segura, Gary, Stanford University, "Collaborative Research: American National Election Studies (ANES) 2014-2017"

Settle Jaime, College of William and Mary, "Understanding the Mechanisms for Disengagement from Contentious Political Interaction"

Schaffner, Brian, University of Massachusetts, Amherst, "Cooperative Election Study, 2010 to 2014 Panel Study"
Slantchev, Branislav, University of California, San Diego, "Borrowed Power: War Finance and the Resort to Arms"

Tomz, Michael, Stanford University, "Collaborative Research: The Democratic Peace-An Experimental Approach"

Weeks, Jessica, University of WisconsinMadison, "Collaborative Research: The Democratic Peace-An Experimental Approach"

\section{DISSERTATIONS}

With Doctoral Dissertation Research Improvement Grants, the advisor is listed first with the student listed second.

Ames, Barry and Cassilde Schwartz, University of Pittsburgh, "A Field Experiment on the Externalities of Protest"

Bauer, Gretchen and Faith Okpotor, University of Delaware, "Explaining PostElection Violence in Africa"

Brinks, Daniel, and Giorleny Altamirano Rayo, University of Texas, Austin, "State Authority and Land Rights in the Americas"

Bunce, Valerie, and Manfred Elfstrom, Cornell University, "Chinese Labor Unrest: Transforming the State from Below?"

Chandra, Kanchan and Adam Harris, New York University, "Ethnic Distance and Voter Behavior in Post-Conflict Democracies"

Chang, Eric C. and Masaaki Higashijima, Michigan State University, "Elections, Electoral Fraud, and Political Conflicts in Authoritarian Regimes"

Downes, Alexander and Seok Joon Kim, George Washington University, "Signal Costs and Public Attitudes toward Foreign Policy"

Ewig, Christina and Casey Ehrlich, University of Wisconsin, Madison, "PostConflict Reconstruction in Colombia"

Gerring, John and Alejandro Avenburg, Trustees of Boston University, "Corruption and Electoral Accountability in Brazil"

Gibson, Clark and Nicolas Obradovich, University of California, San Diego, "Effects of Climate Volatility on Economic Conditions and Voting Behavior in Africa"

Granato, Jim and Kwok Wan, University of Houston, "Voting Dynamics"

Hassner, Ron and Jason Klocek, University of California, San Diego, "State Response to Religious Insurgencies" 
Herring, Ronald and Thibaud Marcesse, Cornell University, "Decentralization, Social Policies, and Clientelism in India"

Huth, Paul and Deniz Cil, University of Maryland, College Park, "Implementation of Peace Agreements and Conflict Recurrence"

Huth, Paul and Peter White, University of Maryland, College Park, "Civil-Military Bargaining, the Threat of War, and the Path to Civilian Control"

Lavine, Howard and Matthew D. Luttig, University of Minnesota, Twin Citiies, "Group Connection and Mass Partisanship"

Levi, Margaret and Carolina Johnson, University of Washington, "An Institutional Theory of Participatory Budgeting"

MacLean, Lauren and Kirk Harris, Indiana University, "Ethnicity, Civic Participation, and Public Goods in Kenya"

Manion, Melanie and Ning Leng, University of Wisconsin, Madison, "Selective Reversal of Public Service Sector Privatization in China"

Manion, Melanie and Samantha Vortherms, University of Wisconsin, Madison, "Reform of China's Household Registration System"

Mertha, Andrew and Christopher Cairns, Cornell University, "Authoritarian Accountability and the Regulation of Online Communication in China"
Pevehouse, Jon and Ryan Powers, University of Wisconsin, Madison, "A Dynamic Theory of Mass Preferences for Trade"

Reiter, Dan and Sabrina Karim, Emory University, "Insurgency, Security Sector Reform, and Local Support"

Roeder, Philip and Paul Schuler, University of California, San Diego, "Deliberative Autocracy: How Single-Party Regimes Manage Liberalized Assemblies"

Sambanis, Nicholas and Kevin Russell, Yale University, "The Role of Identity, Rules, and Values in Public Goods and Accountability"

Shirk, Susan and Weiyi Shi, University of California, San Diego, "How Authoritarian Politics Shapes China's Outward Direct Investments"

Tucker, Joshua and Marko Klasnja, New York University, "Corruption and Incumbency Disadvantage in New Democracies"

Van de Walle, Nicolas and Lauren Honig, Cornell University, "Political Stability, Property Rights, and State-Building in Africa"

Wibbels, Erik and Thomas Gift, Duke University, Doctoral Dissertation Research Improvement Grant: "The Political Economy of Educational Inequality"
Zechmeister, Elizabeth and Mollie Cohen, Vanderbilt University, "The Causes and Representative Consequences of Invalid Voting"

\section{EAGER AND RAPID}

With EAGER and RAPID awards, the first named principal investigator is listed.

Bush, Sarah, Temple University, RAPID: "International Election Observation and Perceptions of Election Credibility"

Feldman, Stanley, SUNY at Stony Brook, "Empathy and Social Welfare"

Golden, Miriam, University of CaliforniaLos Angeles, RAPID: "The Impact of Domestic Election Observers on Electoral Violence, Integrity, and Voting Behavior"

Hale, Henry, George Washington University, RAPID: "Ukrainian Politics Panel Survey"

O'Loughlin, John, University of Colorado at Boulder, RAPID: "Attitudes and beliefs in Russian-supported 'de facto' states and Eastern Ukraine in the wake of the Crimean annexation"

Sniderman, Paul, Stanford University, EAGER: "Exploratory Experiments in Mutual Accommodation"

Stewart, Marianne, University of Texas at Dallas, RAPID: "Russia, Ukraine, and The Dynamics of Public Attitudes Towards U.S. and Global Security"

\section{Keep $P S$ Informed}

Share your news and announcements with $P S$ and our readers. Let us know about your new appointment, new book, or award. Visit https://apsa.wufoo.com/forms/people-in-political-science/. To submit an In Memoriam tribute, contact PS managing editor, Barbara Walthall, at bwalthall@apsanet.org. 